Trab. Ling. Aplic., Campinas, 45(1): 147-164, Jan./Jun. 2006

\title{
DESVENDANDO AS IMPLICAÇÕES POLÍTICO-IDEOLÓGICAS NA CONSTRUÇÃO DISCURSIVO-TEXTUAL DO JORNAL NACIONAL*
}

\author{
FLAVIANE FARIA CARVALHO \\ MARIA CARMEN AIRES GOMES \\ Universidade Federal de Viçosa
}

\begin{abstract}
RESUMO
O objetivo deste artigo é discutir as implicações político-ideológicas nas construções lingüístico-discursivas do gênero discursivo televisual "Jornal Nacional", através da análise textual das editorias de maior frequiência, com base nos pressupostos teórico-metodológicos dos estudos discursivos críticos, em especial aos trabalhos desenvolvidos por Norman Fairclough (1989,2001,2003). Os resultados apontam para a construção de discursos tecnologizados, por meio de uma linguagem sensacionalista, como estratégia de comercialização de notícias.

Palavras-chave: análise crítica do discurso; gêneros discursivos; mídia
\end{abstract}

\section{ABSTRACT}

The aim of the this article is to discuss some important questions on the political-ideological implications inserted in the construction of the discourse of the newscast "Jornal Nacional". Through textual analyses of the editorials of major frequency, the results show the use of the language of sensationalism and "fait-divers" as a strategy of marketing the news. Thus it brings a new contribution to the debate around the theoretical status of Critical Discourse Analysis (Fairclough,2001).

Key-words: critical discourse analysis, genres, midia.

\section{INTRODUÇÃO}

Segundo Marshall (2003), a mídia jornalística está inserida em uma indústria cultural e mercantilista que passa a tratar a notícia não só como uma potência de conhecimentos e informação, mas, principalmente, como um produto de bem de consumo, que deve ser aceito não só pelo público-leitor, mas, e principalmente, pelos anunciantes publicitários. Este teórico define a mídia jornalística, no contexto de pós-modernidade, como um tipo de jornalismo transgênico, isto é, o jornalismo que se modifica em função das leis do mercado, das novas tecnologias e do poderio econômico. Se considerarmos que a mídia jornalística está inserida num momento de mutação, relatividade, transgenia, ambivalência, então é possível que a função informativa (saber-fazer, saber-crer) possa estar adquirindo uma

"Este artigo relata resultados da pesquisa do Projeto Mídia e Discurso: discutindo a mídia telejornalística Jornal nacional no contexto de pós-modernidade, financiado pelo Programa PROBIC/ FAPEMIG/UFV. 
CARVALHO \& GOMES - Desvendando as implicações político-ideológicas...

função mais promocional e espetacularizada, ou seja, a notícia como uma instrumentalização estetizada e mercantilizada, para fins de consumo e desejo. É o que Marshall (2003) denomina de jornalismo "cor-de-rosa", no qual informação e comércio são associados na mesma embalagem trocando, assim, o interesse público pelo interesse do capital.

Termo criado por Howard Kurtz (1993), o jornalismo cor-de-rosa está estrategicamente preparado para não desagradar a ninguém, seja dono, telespectador ou anunciante. A cobertura das notícias mais sérias, que exige maior investigação e profundidade, é substituída por notícias de entretenimento, que têm maior efeito sobre a audiência e custam bem menos à empresa. De acordo com Marshall (2003), esse tipo de jornalismo vive num regime de espetacularização e omissão, em que a regra é estabelecer elementos que atraiam tanto compradores como também investidores.

Neste trabalho, procurou-se analisar e discutir as seguintes categorias lingüísticas: representação do discurso, transitividade e vocabulário, no gênero discursivo televisivo Jornal Nacional, com o intuito de se desvendarem as implicações político-ideológicas decorrentes deste tipo de negociação discursiva midiática.

Por ser o telejornal de maior audiência do país - algo em torno de 31 milhões de pessoas -, escolhemos o JN como objeto de estudo. Ao trabalhar necessariamente com a informação, o JN desempenha um papel fundamental na formação intelectual e crítica de milhões de consciências brasileiras. Mas, como é o trato e a importância dada a essas informações? São informações parciais e manipuladoras ou privilegiam o pluripartidarismo e o interesse público?

Com o intuito de se efetivar uma análise que se distancie ao máximo de grandes eventos esportivos e políticos, como a Copa do Mundo ou as Campanhas Eleitorais, que eventualmente modificam a programação da emissora, a escolha do corpora procurou encontrar um período que estivesse o mais próximo possível de uma semana "normal" na programação da Rede Globo. Nesse sentido, foi escolhida uma amostragem compreendida entre os dias 03 a 17 de outubro de 2003.

Num primeiro momento, foi realizada a cronometragem de todas as matérias exibidas pelo Jornal Nacional durante o período em questão, a fim de identificar quais são as editorias de maior destaque no telejornal. Num segundo momento, foram transcritas todas as notícias presentes no corpora, para que fosse feita a análise do discurso verbal do JN, embasada no quadro tridimensional de Fairclough (2001). Neste artigo, será demonstrada a análise lingüístico-discursiva das notícias exibidas nas editorias que obtiveram maior freqüência, a fim de relacionar os dados quantitativos resultantes da cronometragem com os dados qualitativos e interpretativos advindos da análise textual.

\section{ANÁLISE DOS DADOS}

\subsection{Cronometragem das editorias: algumas resultantes}

Diante do quadro inicial de análise, podemos tecer algumas conclusões. Ao destinar um tempo considerável às editorias Internacional, Polícia e Esporte, o JN evidenciou a 
Trab.Ling.Aplic., Campinas, 45(1) - Jan./Jun. 2006

sua linguagem na pós-modernidade: a do jornalismo cor-de-rosa, um amálgama estético no qual predominam apologias ao sensacionalismo, à espetacularização e aos fait-divers. A própria edição fragmentada e desconexa das notícias tenta tranqüilizar o consumidor, induzindo-o à conclusão de que tudo está em equilíbrio.

Quando se afirma que o telespectador é encarado pelo noticiário como consumidor, isso implica dizer que a figura do receptor-cidadão foi descartada a partir do momento em que a intenção de se educar as massas foi esquecida. Editorias como Meio Ambiente, Social e Cultura não são recorrentes diariamente e, quando são, esporádicos são os programas que dispensam um trato mais aprofundado a suas temáticas.

Nesse sentido, o JN parece incapaz de acender a chama do debate público, do cidadão consciente e responsável. Em decorrência de tal prática, postulamos então que sua intenção seja harmonizar e não promover o choque de idéias, o conflito.

Entre os temas mais abordados, durante a exibição analisada, o telejornal Jornal Nacional deu um maior destaque às editorias Internacional, Esporte e Polícia. Isso evidencia o caráter dúbio, polêmico e heterogêneo do jornal, uma construção discursiva constitutivamente diversificada, dirigida a um telespectador múltiplo e ávido por uma infinidade de fatos e acontecimentos, mesmo que de forma fragmentada. Esses dados podem ser observados abaixo, na tabela 1:

\begin{tabular}{|c|c|c|}
\hline Editoria & No. Matérias & Duração \\
\hline Polícia & 25 & $\mathbf{2 9 , 0 2}$ \\
\hline Esporte & $\mathbf{2 5}$ & $\mathbf{3 6 , 6 3}$ \\
\hline Internacional & $\mathbf{4 6}$ & $\mathbf{6 0 , 8 8}$ \\
\hline
\end{tabular}

A aparente avalanche de informações, fornecidas pelo JN, tende mais a desviar a atenção do telespectador dos problemas latentes na sociedade brasileira do que realmente promover um quadro de debates informativos, analíticos e críticos sobre os assuntos relatados. A fragmentação e a efemeridade dos fatos relatados obscurecem de certa forma o desenvolvimento de uma sociedade mais crítica e reflexiva, desencadeadora de mudanças sócio-culturais (Carvalho e Gomes,2004).

\subsection{A construção dos discursos no JN}

Com base no quadro tridimensional de Fairclough (2001), analisaremos o texto das editorias de maior recorrência no JN: Internacional, Esporte, Polícia e Política. A partir dos significados das formas lingüísticas, segundo a proposta de Halliday (1994), foram escolhidas as seguintes categorias de análise: vocabulário, discursos direto e indireto, vozes ativa e passiva, pressuposição, modalizador e nominalização.

A título de esclarecimento, consideramos pertinente a definição do termo fait-divers, categoria encontrada com muita frequiência nas notícias. Segundo Marshall (2003), os faitdivers são as categorias de notícias banais baseadas em seu caráter sensacional e espetacular, apresentando tipos de relatos sobre fatos absurdos, inusitados e curiosidades sobre a vida privada de celebridades ou mesmo de pessoas comuns. São, portanto, notícias que, embora 
CARVALHO \& GOMES - Desvendando as implicações político-ideológicas...

de importância duvidosa, normalmente atingem diretamente a necessidade do público por informação, além de funcionarem como chamariz para atrair telespectadores e audiência.

Feitas as considerações acima, iniciemos a análise textual pela editoria de maior recorrência no telejornal: Internacional.

\subsubsection{Editoria Internacional}

Editoria de maior ocorrência no telejornal, Internacional apresenta-se com fortes doses de sensacionalismo. Isso pode ser comprovado, inicialmente, pelos principais temas noticiados pelo JN durante o período analisado: terrorismo, atentados e conflitos no Oriente Médio, a busca por Saddam Hussein, a crise na Bolívia.

A produção se desenvolve como se os problemas se concentrassem lá fora, bem distantes da "ilha de tranqüilidade brasileira". Com efeito, não podemos perder de vista a estratégia do "jornalismo-cor-de-rosa", uma vez que o JN, a fim de amenizar a tensão provocada por tais notícias, veicula matérias "bem humoradas” das eleições na Califórnia e faz uso de fait-divers, estes últimos presentes nos seguintes exemplos:

Um sargento do exército americano ganhou 150 milhões de dólares na loteria dos Estados Unidos. X serve na Coréia do Sul e estava de férias visitando a família no estado da Geórgia quando comprou o bilhete. (JN 03/10/03).

Um tigre de 200 quilos e 1 jacaré de 1 metro e meio foram levados de um apartamento em Nova Iorque para reservas animais nos Estados Unidos.. (JN 04/10/03)

A comemoração de um casamento provocou a queda de um avião na Europa. Atirar para o alto depois da cerimônia é uma tradição na Sérvia e Montenegro. Só que desta vez os tiros atingiram um avião de dois lugares. Segundo uma testemunha o avião voava baixo. O piloto e o carona que ficaram feridos gravemente não tinham licença para voar. (JN 13/10/03)

Taiwan terá no mês que vem o edifício mais alto do mundo, com 508 metros.. (JN 17/10/03)

Pelo fato desta editoria ser composta por diferentes temas, resolvemos analisá-la a partir da divisão das notícias mais freqüentes, como pode ser observado a seguir:

\section{- EUA x Saddam}

As nominalizações são freqüentes e referentes a Bush e, ainda, utilizadas com o intuito de converter as ações concretas do governo norte-americano em práticas abstratas. Junto às nominalizações, a modalização age no sentido de atenuar as ações de Bush contra o Iraque. Nesse sentido, o JN aponta alguns sinais de comprometimento com as proposições relacionadas aos EUA, permitindo que perspectivas parciais sejam universalizadas pela mídia (Fairclough, 2001).

O uso de passiva é sempre atribuído a Saddam Hussein, imprimindo-lhe um caráter de culpa, de acusado: 
Trab.Ling.Aplic., Campinas, 45(1) - Jan./Jun. 2006

O serviço de informação do exército americano afirmou hoje que o ex-ditador Saddam Hussein foi visto recentemente em Chicrit, a cidade onde nasceu, no norte do Iraque... (JN 13/10/03)

O discurso indireto somado ao uso de elementos indicadores de pressuposições (até agora, não gostou, nunca reativou, relatório ainda, o que já, uma ameaça, vão continuar) criam uma relação conflituosa ora de concordância, ora discordância entre a voz do jornal, a voz atribuída a Bush e as implicações acerca da culpa de Saddam Hussein, para relatar os discursos e as ações do governo norte-americano, como se pode notar no fragmento abaixo:

O relatório que trouxe do Iraque diz que as investigações mostraram atividades suspeitas, existência de laboratórios e programas para a construção de mísseis proibidos. Mas o ponto central permanece o mesmo. Até agora nenhuma arma de destruição em massa foi encontrada. A oposição não gostou do que ouviu. O senador democrata $\mathrm{W}$ disse que segundo o relatório, o Iraque nunca reativou o seu programa nuclear e não tinha capacidade para uso de armas químicas em campo de batalha. W quer saber porque a espionagem americana estava tão iludida. Na Casa Branca a reação foi partir para o ataque. Logo de manhã o presidente Bush disse que o relatório ainda é parcial. Segundo ele mesmo o que já foi descoberto prova que Saddam Hussein está enganando a ONU e seria uma ameaça para o resto do mundo. 1200 inspetores vão continuar no Iraque pelos próximos meses.(...) (JN 03/10/03)

A incorporação de elementos e vozes de outros textos de forma atribuída (por meio do discurso indireto) nos indica quais são as vozes fundamentais para se construir a narrativa da guerra. Vale ressaltar ainda que o uso das vozes (Bush, relatório, o senador democrata $W, W$ quer saber, segundo ele mesmo) sinaliza para um cenário conflituoso entre os próprios políticos da Casa Branca sobre os motivos que levaram os EUA a invadirem o Iraque. O uso das pressuposições somado à atribuição de vozes sustenta o discurso hegemônico do império, do mercado, do capitalismo, do autoritarismo...

A retórica da "guerra ao terror", usada pelos governantes submetidos aos ditames do neoliberalismo, cujo maior expoente é Bush, serve para atacar qualquer país pouco disposto a aceitar as "regras do mercado", como foi o caso do Iraque ou da Palestina, como veremos a seguir:

\section{- Atentados no Oriente Médio}

O recurso da narrativa é o pano de fundo para descrever o espetáculo do terror; ao usar tal recurso, o JN distancia-se do problema/da complicação da guerra, mas ao denominar os protagonistas, enfatiza as distinções, diferenças e divisões, ressaltando as singularidades que desunem os povos no Oriente Médio, constituindo assim identidades efetivas de exercício de poder. Nesse contexto, a agência está associada à ação dos terroristas:

Feriado de Sabá, dia de sol, restaurantes lotados. Um deles em Raifá, na beira do mediterrâneo, foi o alvo da mulher-bomba. Ela matou o segurança para abrir caminho e entre as mesas detonou os explosivos que levava amarrados à cintura. $\mathrm{O}$ ataque na véspera do Yon Kippur, dia sagrado para os judeus acabou com a calmaria que já durava 25 dias na Terra Santa. Desde ontem os grupos Hamás e Gihah faziam ameaças. Os terroristas avisavam que este muro de 430 quilômetros 
CARVALHO \& GOMES - Desvendando as implicações político-ideológicas...

de extensão e 25 metros de altura que está sendo construído em torno dos territórios palestinos não impediria as ações dos suicidas contra os israelenses. (JN 04/10/03)

Houve tiroteio intenso. Os palestinos admitiram que os soldados mataram 2 militantes, mas disseram que os outros mortos eram civis desarmados. Um assessor de Yasser Arafat classificou a operação de crime de guerra e catástrofe humanitária. Já um assessor de Ariel Sharon disse que Israel foi obrigado a realizar um trabalho que deveria ser executado pela autoridade palestina, numa referência à caça de terroristas. (JN $10 / 10 / 03)$

O uso do relato de tiroteios, de bombas explodindo e ferindo civis pode ser vista como uma estratégia de retórica do terror, uma espécie de publicização de ações antagônicas entre Arafat e Sharon, o JN tenta convencer a opinião pública que os dois protagonistas e suas ações são pertubadoras, conflituosas, "inimigos da humanidade", mas faz isso de uma forma distanciada, não se posicionando sobre tais informações. O JN tenta legitimar seu discurso por narrativização, relatando estórias como se fizessem parte de uma tradição eterna, verdades inquestionáveis. Ou seja, por que questionar uma guerra tão antiga e estabelecida ideologicamente?

A voz passiva é também utilizada para evidenciar, com forte teor sensacionalista, a vitimização de crianças em conflitos e atentados. A passivização ofusca a agência, o culpado pelas mortes e pelos momentos de angústia, auxiliando ainda na retórica do terror: estória simples, dramática, atributos de vitimização, enfatizando o discurso sensacionalista, corde-rosa. Observa-se, desse modo, a eficácia das estratégias de singularização das exibições da infelicidade humana praticadas pelo telejornal:

\begin{abstract}
A mãe do menino brasileiro ferido em atentado no Líbano vai viajar esta noite pra ficar ao lado do filho em Beirute. (...)O menino Armed Sirin de 4 anos está internado no hospital desde a semana passada, quando um míssil atingiu o quarto da casa em que ele estava em Rolah, sul do Líbano. O irmão do menino morreu na explosão. (JN 13/10/03)
\end{abstract}

A mãe do menino brasileiro atingido por um atentado terrorista no Líbano chegou hoje à Beirute.(...)

Rep: Armed Assimi de 4 anos está internado desde a semana passada no hospital de Beirute. Daqui a uma semana deve ser operado novamente para estilhar estilhaços da bomba da cabeça. $\mathrm{O}$ irmão dele Ali de 5 anos morreu no atentado. O pai de Armed, que também está em Beirute, disse que o menino já está se recuperando bem. (JN 16/10/03)

Para Lochard (1996), os enunciados de discurso relatado proferidos pelos anônimos são presididos por um comportamento elocutivo marcado pela subjetividade. As marcas de subjetividade afetiva se multiplicam, freqüentemente, nas palavras dos anônimos. No caso das vítimas, o uso do discurso direto somado ao de modalizadores (ansiosa, poucas notícias) pelo JN é um exemplo explícito de apelo emocional:

Rep: A mãe estava ansiosa.

Ent (mãe): Alô, sei, sei. 
Trab.Ling.Aplic., Campinas, 45(1) - Jan./Jun. 2006

Rep: Desde o atentado na madrugada de segunda-feira no sul do Líbano, Sandra tinha poucas notícias do filho de 4 anos que sobreviveu ao ataque. Hoje a tarde, por telefone, conversou com o pai dos meninos, o libanês W. A primeira pergunta foi pelo filho que morreu.

Ent (mãe): O que aconteceu com o Ali, fala pra mim, ah?

Ent (pai): Ali faleceu.

Ent (mãe):Como, o que aconteceu com ele?

Ent (pai): Uma perda, uma perda. (JN 10/10/03)

Já no que tange à política de Israel, o discurso direto atua como porta-voz de suas ações, visando a criar um efeito de autenticidade, objetividade e seriedade nas decisões do governo israelense. Outra prova da postura parcial do JN se mostra no uso descrições definidas coletivas (autoridades israelenses, exército israelenses, Nasser do parlamento de Israel, governo israelense, autoridades palestinas) nominalizações (expulsão e exílio) para construir um discurso ora de legitimação de culpa ora de omissão do agente responsável, ou seja, mais uma vez o JN cria um discurso conflitante e distanciado, sem informações opinativas e avaliativas, atribuindo sempre vozes aos protagonistas dos atos "perversos":

As autoridades israelenses reagiram: "Agora é tarde demais para discursos demagógicos", disse o porta-voz do governo de Israel. Enquanto o exército israelense prometia uma represália, Nasser do parlamento de Israel voltava a defender a expulsão do dirigente palestino Yasser Arafat. No mês passado, o governo israelense ameaçou mandar Arafat para o exílio. A idéia não foi adiante por causa das pressões internacionais e principalmente porque as autoridades palestinas prometeram se empenhar para impedir novos ataques terroristas. (JN 04/10/03)

Uma segunda marca de subjetividade empregada pelo telejornal é o uso do modalizador querer associado ao governo da Síria, nos momentos em que este condena ou imprime denúncias ao governo israelense.

A ênfase em números de mortos e feridos em atentados, e o vocabulário pertencente ao universo bélico repleto de mísseis, guerra, terrorismo, explosivos, mulher-bomba, detonou, suicidas, mortes - para fins de espetacularização da notícia - são estratégias praticadas assiduamente pelo telejornal, para criar o que denominamos como a narrativização da guerra.

\section{- Crise na Bolívia}

Mais uma vez, a narrativa é utilizada para descrever a crise, retomar o terror e representar a tensão do conflito. Há um aparecimento freqüente de outras vozes, por meio do discurso direto: por um lado, opta-se pela atribuição de voz ao embaixador do Brasil; por outro, privilegia-se os depoimentos carregados de léxicos emoção, com forte carga de subjetividade (assustado, perigoso, terrível, assustado, destruído, queimados, sem água, sem comida, difícil esquecer) de turistas brasileiros na Bolívia e de imigrantes bolivianos no Brasil:

Ent (sobrinha): Estou muito agradecida com o governo brasileiro por ter me ajudado a chegar aqui. 
CARVALHO \& GOMES - Desvendando as implicações político-ideológicas...

Rep: Os passageiros contaram que de madrugada em La Paz foram escoltados pelo exército boliviano até a base aérea para esperar o avião brasileiro.

Ent: Foi terrível. A noite agora em comboio a gente saiu, foi muito perigoso. Foi terrível. A gente fica muito assustado.

Ent (professor): A estrada de acesso ao aeroporto está completamente destruída.

Rep: O que o senhor viu no trajeto?

Ent (professor): Olha, carros queimados, troncos, pedras, até vagões de trem eles usaram pra bloquear essa estrada.

Rep: Difícil esquecer a experiência boliviana. Essa turista que estava no interior do país teve de voltar por conta própria pra La Paz.

Ent (médica): Tivemos que caminhar 48 quilômetros a pé, sem água, sem comida, uma tristeza. (JN 17/10/03)

Essa forte carga de subjetividade resultou em uma verdadeira dramatização do discurso do ufanismo, de exaltação da pátria e dos valores nacionais, que culmina com o canto do hino nacional, ou seja, o mal-estar sofrido pelos protagonistas da narrativa torna-se digno de ser notícia, porque além de ser comercialmente rentável e dramático, tenta convencer a opinião pública de que o Brasil é o melhor local para se viver, pois está isento de guerras, mortes, ataques terroristas...como se a pobreza, a miséria, o tráfico entre outras tantas questões sociais não nos causassem tanto sofrimento:

Rep: Os brasileiros se juntaram num coro orgulhoso e cantaram o hino nacional.

E ficaram emocionados com o espírito de solidariedade dos brasileiros. De lembrança ele guarda o reconhecimento pelo povo brasileiro, que segundo o estudante, fez pelos estrangeiros o que nenhum outro país faria. Os brasileiros sabem bem o que isso significa.

Ent (médica): Nós passamos por um sofrimento muito doído, e aí a gente dá o valor que devíamos dar sempre pela nossa pátria, pela nossa terra. Isso aqui realmente é o paraíso. (JN 17/10/03)

O discurso indireto é também bastante utilizado, a fim não só de traduzir as falas citadas tanto dos manifestantes quanto das autoridades envolvidas, mas também, principalmente de atribuir vozes aos protagonistas da narrativização.

O vocabulário, amiúde sensacionalista, é composto por morte, violência, atrocidade e crise. Sem falar nos léxicos que remetem ao campo semântico negativo da guerra, como é o caso de violência, morreram, choque, tanques, confronto, exército, soldados.

\section{- Eleições na Califórnia}

O discurso indireto é bastante utilizado e tem o propósito de relatar os discursos atribuídos às vozes legitimadas das polêmicas envolvendo o candidato Schwarzenegger, levando o JN a se distanciar destas questões conflituosas:

Rep: Nada de armas pesadas como as que são vistas nos filmes do exterminador. O símbolo da campanha de Arnold Shwarzenegger é uma vassoura. Segundo ele para varrer os democratas da Califórnia. Mas o republicano não conseguiu limpar uma mancha que aumentou na última semana. 15 mulheres o acusaram de assédio sexual. Esta canadense afirma que ele levantou a saia dela num estacionamento. A outra conta que o ator a agarrou e beijou à força num local de uma 
Trab.Ling.Aplic., Campinas, 45(1) - Jan./Jun. 2006

filmagem. E esta mulher disse que Shwarzenegger apalpou os seios dela numa academia de ginástica. $\mathrm{O}$ candidato não se explicou direito. Disse que isso faz parte de uma campanha sórdida dos adversários. Grupos feministas protestaram. E segundo os analistas políticos, as eleitoras são as responsáveis pela mudança nas pesquisas de opinião divulgadas no fim de semana.

$(J N$ 06/10/03)

Vale ressaltar que o JN vale-se de determinados léxicos nas referências a Schwarzenegger, por exemplo, imprimindo-lhe uma construção de identidade híbrida, isto é, um mix de características pessoais e ficcionais, muitas vezes, desempenhando o papel tanto de objeto como de agente dos processos, jogando luz sobre pressupostos - talvez irônicos - e estratégias que não são tornados explícitos pelo telejornal, levando, inclusive, aquele telespectador desavisado a se confundir se o candidato é o personagem ou a pessoa física:

Rep: vitória do astro de Hollywood. No melhor estilo exterminador, Arnold Shwarzenegger $\mathbf{O}$ fortão também aniquilou os mais de 100 concorrentes, com $48 \%$ dos votos. Um desempenho que os analistas atribuem ao carisma e a imagem de vencedor cultivada por Shwarzenegger. Mesmo sendo republicano. O desafio que o exterminador tem pela frente é bem real. E o legislativo do estado é de maioria democrata, mesmo partido do vice-governador. Mas nada parece intimidar o imigrante que começou a carreira exibindo os músculos. Personificou todo tipo de valentão no cinema.. Qualquer semelhança não é mera coincidência. (JN 08/10/03)

No tema em questão, a passivização tem a função de transformar Schwarzenegger em vítima, quando a este são dirigidas acusações por ter feito um elogio a Hitler. Ainda, o futuro do pretérito (teriam sido) somado a uma nominalização (as declarações) assume um papel preponderante: o de atenuar tais acusações e ofuscar quem fez tal elogio:

O ator e candidato republicano ao governo da Califórnia Arnold Shuwarzenegger foi acusado de ter expressado admiração por seu conterrâneo Adolf Hitler no passado. Os dois nasceram na Áustria. As declarações teriam sido dadas a um amigo há 28 anos e publicadas pelo jornal New York Times e pela rede d2e televisão ABC. Shuwarzenegger teria dito que admirava Hitler porque o nazista começou como um homem quase sem instrução e chegou ao poder(...). (JN 03/10/03)

\subsubsection{Editoria Esporte}

Segundo Morin (1984), jogo e espetáculo mobilizam uma parte do lazer moderno. Nada disso é absolutamente novo, pois os espetáculos, assim como os jogos, sempre estiveram presentes nas festas e nos lazeres antigos. O que constitui novidade é a extensão televisionária do espetáculo, abrindo-se até os horizontes cósmicos, são os progressos de uma concepção lúdica da vida.

Seja no futebol, no vôlei ou em Fórmula 1, podemos constatar que o telespectador do $\mathrm{JN}$ é destacado do espetáculo, reduzido ao estado passivo de voyer e de consumidor. O voyerismo se confirma nas matérias esportivas que anunciam curiosidades, confidências, revelações sobre a vida particular dos "atletas-heróis": 
CARVALHO \& GOMES - Desvendando as implicações político-ideológicas...

Rep: Hoje elas treinaram, mas no fim de semana queriam distância de vôlei. Sandra numa ilha, Ana Paula na serra, estratégia para enfrentar uma semana puxada.

Ent (Ana Paula): Então quando a gente tem um final de semana tem que curtir mesmo e evitar de falar de voleibol pra quando voltar, aí tá bem focada de novo. (JN 06/10/03)

Ent (Adriana): Temos que dividir no caso a quadra, quarto, estamos juntas nos vôos, temos que decidir tudo junto. Então isso tudo muitas vezes gera alguns problemas. (JN 07/10/03)

Através desta transformação de informações de interesse humano - os fait-divers em (pseudo) notícia, configura-se no $J N$ a presença da publicidade: esses retalhos da vida dos atletas funcionam como iscas para prender a atenção do telespectador até o dia da ocorrência do evento esportivo que, não por mera coincidência, é sempre transmitido pela Globo.

A contaminação e a deteriorização do conceito de jornal diz respeito, aqui, à promiscuidade existente entre informação e propaganda, em que a notícia perde sua missão precípua de reportar e passa a carregar os interesses de propagandear produtos, idéias, ou personagens, numa radical inversão de valores (Marshall: 2003):

Her: E amanhã a Globo transmite o desafio Brasil e Portugal de futsal ao vivo no Esporte Espetacular, que começa às 9 e meia da manhã. (JN 04/10/03)

Her: A Globo transmite o GP do Pacífico ao vivo, na madrugada deste domingo. A corrida começa às duas horas da manhã. (JN 04/10/03)

Fat: Daqui a pouco o Campeonato Brasileiro ao vivo na Globo, logo depois de Mulheres Apaixonadas. Uma boa noite pra você. (JN 08/10/03)

Fat: A Globo mostra o treino que decide a formação do gride de largada logo mais depois do Jornal da Globo. E amanhã a partir das 10 da manhã você vai acompanhar também ao vivo o jogo de Adriana Behar e Shelda pelas semifinais do mundial de vôlei de praia. (JN 10/10/03)

Dessa forma, o noticiário exibe a matéria para, logo em seguida, divulgar o dia e o horário de transmissão das competições pela emissora global, numa estratégia de autopromoção. Verifica-se, assim, a seguinte tendência: a busca da identidade e do elo com o telespectador e a publicidade (Guimarães: 2001).

A narrativização, mais uma vez, é um elemento fundamental na descrição quase mitificada da trajetória dos heróis, de sua vida e de suas vitórias, onde ficam explícitas a exaltação ao patriotismo brasileiro:

Bon: Um atleta brasileiro está a 2 dias de recuperar um prazer que por muito tempo foi apenas sonho. Rep: Narciso se recuperou. Em janeiro de 2000, abandonou o futebol. Começou a luta para vencer a leucemia. Depois de um transplante, a torcida passou a ser para o organismo não rejeitar a medula doada pela irmã. Quando voltou ao Santos no ano passado, ainda precisava recuperar os 19 quilos perdidos durante o tratamento. No domingo, contra o Atlético Paranaense, vai ficar no banco. Um quilo acima do peso ideal: 79.

Ent (Narciso): A gente sabe que foi uma luta difícil, porque não é fácil se recuperar, principalmente com uma doença tão séria como eu tive, mas o pensamento sempre foi poder voltar. 
Trab.Ling.Aplic., Campinas, 45(1) - Jan./Jun. 2006

Rep: A notícia de que podia voltar a jogar futebol foi apenas a primeira alegria de Narciso esta semana, a outra foi o nascimento de Ruan, o segundo filho do jogador. (JN 17/10/03)

Sob este viés, notam-se traços de forte subjetividade, como o uso do modalizador querer em algumas matérias:

Rep: Elas só podem ser alcançadas pelas brasileiras Adriana Beah e Shelda e pelas americanas X e Z, vice-líderes do ranking que hoje treinaram na arena da competição. X reconhece que dificilmente vai conseguir evitar a conquista da dupla brasileira, mas quer muito vencer no Rio de Janeiro. Se elas querem muito, imagine as donas da casa. Ana Paula vai atrás do título com uma inchação no polegar da mão esquerda que ainda incomoda. Shelda teve uma bronquite muito forte. Ficou uma semana de cama. Voltou a treinar no fim da semana passada e vai jogar tomando antibióticos. (JN $06 / 10 / 03)$

Há pouco uso de nominalizações, sendo que a expressão Seleção Brasileira já pode ser considerada como cristalizada pela língua, servindo também como estratégia para reforçar o ufanismo coletivo de que a Seleção é o próprio Brasil.

Logo, compreendemos que, além de divertir e proporcionar o lazer ao telespectador, a editoria Esporte do JN favorece os objetivos nacionalistas e ideológicos do Estado, além dos capitalistas de produção, enfatizando e oportunizando também os bens de consumo produzidos através das publicidades transmitidas. Estas condições associadas ao esporteespetáculo trazem grandes receitas aos dirigentes do esporte, aos proprietários da emissora, e lucros aos patrocinadores (Guimarães, 2001).

Os raros momentos em que aparece a voz passiva são caracterizados por atribuir um significado depreciativo a determinados coadjuvantes envolvidos na matéria. Vale ressaltar, ainda, que o JN representa aqueles que não pertencem ao endogrupo da Seleção Brasileira através de ironias, caracterizando-os como exogrupo (inglesinhos, coitados, temiam, papel de bobos, lado de fora). A seleção léxica reforça a identidade do outro como idiotizado, fraco, diminuindo seus atirbutos.

Rep: Três inglesinhos foram escolhidos para completar o time reserva para o coletivo da Seleção. E logo na defesa, coitados! Temiam, sabiam que estavam ali para fazer papel de bobos. Era melhor ter ficado do lado de fora como torcedores.. (JN 10/10/03)

O que predomina é a agência dos atletas consagrados no mundo do esporte, dandolhes vivacidade, ação e garra, atributos positivos pertencentes aos heróis:

Bon: Os milhões de terráqueos que acompanham apaixonadamente às corridas da Fórmula 1 neste início de século já garantiram uma boa história para contar aos filhos e aos netos. Eles podem dizer que assistiram à conquista histórica do piloto mais vitorioso de todos os tempos. $\mathrm{O}$ alemão Mickael Shumaker quebrou quase todos os recordes da categoria. Tornou-se o único hexacampeão mundial

Rep: O primeiro ato de Shumaker hexacampeão foi o abraço demorado e agradecido em Barrichello. Isso resume o que é Mickael Shumaker além do que o mundo já sabe: o maior vencedor da história da Fórmula 1.

(JN 13/10/03) 
CARVALHO \& GOMES - Desvendando as implicações político-ideológicas...

Em alguns momentos, emprega-se o modalizador poder acompanhado do futuro do pretérito, a fim de proteger os "olimpianos" de possíveis ameaças à face. Nesses casos, a modalidade é objetiva, na qual a base subjetiva e o grau de afinidade com as proposições dos agentes encontram-se implícitas no discurso:

Rep: Só em 2003, quase 70 jogadores deixaram o país. Muitas vezes eles vão receber salários de 50, 60 mil reais. Ou seja, o triplo do que se paga por aqui. Há pelo menos 2 anos países como Espanha e Itália passaram a contratar o que há de melhor no futsal brasileiro, o que acaba sendo um problema para a seleção porque ao contrário do futebol, os clubes europeus não são obrigados a liberar os jogadores nas convocações. Atualmente há uma lista de 15 craques no exterior que poderiam deixar a equipe mais forte. (JN 04/10/03)

O discurso indireto praticamente não ocorre, cedendo lugar ao uso demasiado do discurso direto legitimado, representado, em sua maioria, pelos jogadores das competições, a fim de proporcionar autenticidade e emoção à notícia. Outras vozes aparecem, porém com ínfima recorrência: são as vozes do diretores dos clubes ou técnicos.

A utilização de léxicos como disputa, competição, enfrentar, arena, vencer, conquista, apontam para o campo semântico do combate, atração típica do discurso do espetáculo, ou seja, a o esporte também como uma arena de conflitos, vaidades, garantindo ao público telespectador mais emoções do que informações factuais.

\subsubsection{Polícia}

Na tendência sensacionalista em que se insere o JN, ocorre a desenfreada busca de fatos e quanto mais tensos, melhor, maior será a audiência - daí a importância mercadológica desta editoria. Em geral, as matérias obedecem ao perfil da condenação, ideologicamente pautada pelo maniqueísmo e pelo denuncismo.

Este perfil trata o ser humano dentro da redução mocinho/bandido, espécie de maquiamento responsável por ocultar a estratégia disciplinar, na qual se pauta o JN. Afinal, precisamos assistir a notícias de violência e do Mal para nos considerarmos sujeitos éticos, visto que o negativo aponta necessariamente para o positivo.

Nesse sentido, os temas em Polícia tratam de assassinato, roubo, agressão, fraudadores, contrabandistas e corrupção, em que instintos se tornam violências, golpes, homicídios, em que medos se tornam suspenses, angústias. É a vida que conhece a liberdade, na qual o homem (telespectador) não está mais à mercê da norma social: a lei. (Morin, 1984)

Isso porque o homem civilizado, regulamentado, burocratizado, o homem que obedece aos agentes, aos editais de interdição, se libera projetivamente na imagem daquele que ousa tomar o dinheiro ou a mulher, que ousa matar, que ousa obedecer à sua própria violência (Morin, 1984).

A lógica do pensamento deste autor fica ainda mais evidente no vocabulário expresso pelo JN: principal suspeito, homem suspeito, acusado, maior contrabandista, o principal alvo da CPI, ladrões, quadrilha, vítimas, agressor, homem preso. Os grandes criminosos seriam, portanto, os bodes expiatórios da coletividade. 
A agência, nesta editoria, está associada aos atos "positivos" e ativos (descobriu, encontrou) da polícia, evidenciando um discurso positivista de uma instituição tão ameaçada pelas denúncias de abusos e corrupção:

Gar: A polícia de Minas Gerais descobriu hoje em Uberlândia uma quadrilha que fabricava e distribuía CDs pirata. Nas 3 casas investigadas, a polícia encontrou notas fiscais, cheques $e$ anotações sobre a entrega dos CDs. Segundo a polícia, o material pirateado seria enviado para Goiás, Bahia, Mato Grosso e Paraná. (JN 04/10/03)

Já a nominalização (o laudo, o roubo, retratos, a relação) divide com a voz passiva (foram roubados, foi descoberto, foram reproduzidos, foi colocada) a possibilidade de omitir o agente e a variedade de motivações para fazê-lo:

Bon: O governo federal reforçou hoje a segurança no Palácio do Itamaraty, no centro do Rio, de onde foram roubados documentos raros, entre mapas e fotos.

Rep: O laudo foi na mapoteca do antigo Palácio do Itamaraty no Rio, onde funcionou o ministério das relações exteriores. Os ladrões entraram em diversas salas do prédio e tiraram documentos de armários e arquivos. É um lugar fechado ao público, com acesso permitido apenas a pesquisadores e funcionários. O roubo revelado agora foi descoberto em julho durante uma pesquisa de rotina. Sumiram 150 gravuras, fotos, e documentos que foram reproduzidos num livro editado na década de 90. Mapas originais das rotas de navegação, do tempo das capitanias hereditárias, dos tratados de fronteira do país e mais álbuns do Barão do Rio Branco e do fotógrafo W. Também desapareceram retratos da família imperial brasileira. A relação das obras roubadas foi colocada na internet, na página do instituto do patrimônio histórico e artístico nacional. Impressa, a relação dá 10 folhas, com a descrição dos mapas, fotos e documentos que desapareceram. Por enquanto a polícia federal mantém a investigação sob sigilo. A principal pista é o próprio comportamento dos ladrões, que chegaram a devolver parte das obras 1 semana depois do roubo.

Ent (Assoc. Bras. de Cartografia): Porque uns foram devolvidos e outros não. E aí nessa questão você pode sair do campo da especulação para um roubo de mandado, ou seja, alguém queria aquela peça especificamente por algum motivo.

Rep: A segurança do palácio foi reforçada depois do roubo. E deve ser instalado um circuito interno de televisão.

Ent (pesquisador e editor de arte): Era uma coisa tão frágil, aqui você entrava e saía e tinha só um funcionário tomando conta, eu nunca vi um equipamento de televisão à altura, um controle de segurança à altura. Eu acho que isso era uma crônica de uma morte anunciada, num certo sentido. Bon: O Itamaraty declarou em nota que a polícia federal está investigando o caso e que a Interpol também foi comunicada sobre o roubo. (JN 06/10/03)

A voz passiva está associada ao uso de vocábulos, como: corpos, roubos, vítima, suspeitas, para não tornar evidente a violência brasileira:

Rep: No depoimento à polícia, o homem preso há uma semana admitiu que esteve com X de dez anos num hotel, mas negou que tenha cometido o crime. $O$ corpo do menino foi encontrado há um mês num matagal. Na reconstituição, o suspeito deveria mostrar à polícia o local para onde teria levado $\mathbf{X}$ depois de sair do hotel. Mas acabou indicando o lugar onde foi encontrado $\mathbf{o}$ corpo de uma outra vítima, o vendedor de rapaduras $\mathrm{Y}$ de doze anos.

Rep: As mostras de sangue do suspeito já foram encaminhadas para a comparação do material coletado na roupa do menino. A polícia agora também suspeita que o vendedor esteja envolvido no assassinato do índio $\mathrm{W}$ de dez anos. O garoto desapareceu perto do hotel em que o homem se 
CARVALHO \& GOMES - Desvendando as implicações político-ideológicas...

hospedava. E a forma como foi morto, por estrangulamento, é semelhante a dos outros dois meninos. O delegado vai pedir um laudo psiquiátrico do suspeito. Nos últimos doze meses, nove crianças foram assassinadas na região de Passo Fundo. A polícia ainda suspeita da relação das mortes com o tráfico de drogas. (JN 03/10/03)

Tal prática sugere uma possível significação política e ideológica, pois, como afirma Fairclough (2001), uma questão importante é se a agência, causalidade e responsabilidade são tornadas explícitas ou deixadas vagas nos relatos de eventos importantes na mídia, para amenizar as ações da polícia, preservando a ordem hegemônica social.

Um ponto interessante é o uso do futuro do pretérito para amenizar críticas feitas a alguém do governo ou alguma autoridade legitimada da polícia (deveria ser retirado, teria estar) atenuam os julgamentos emitidos pelo $J N$ contra os "possíveis" acusados, resultando na condenação implícita do "bandido".

Há uma variedade de pressuposições atribuídas aos acusados, utilizadas com a intenção de manipular e influenciar a opinião pública, visto que são freqüentemente difíceis de desafiar: nova pista, ainda suspeita, não deixam mais, agora também, medo mudou, não consegue mais, principalmente agora, agressões começaram, ainda bate, agora está, se tornou, só, etc. Estas, por sua vez, circulam nas notícias como expressões prontas e acabadas, ou melhor, como verdades incontestáveis sobre os fatos, investigações e processos.

A promoção de outras vozes ora é dada pela voz legitimada do delegado ou da instituição legalizada - o que confere às notícias certo grau de objetividade -; ora é manifestada pela voz da mãe, de amigos e parentes ou da própria vítima, vozes anônimas carregadas de sentimentalismo para finalizar a matéria espetacularizada.

Na tendência sensacionalista, como observa Medina (1998), ocorre a desenfreada busca de fatos e, quanto mais tensos, melhor. Paralelamente, a tendência à simplificação muitas vezes está em pé de igualdade com a tendência ao maniqueísmo; polariza-se mais nitidamente que na obra original o antagonismo entre o bem e o mal; acentuam-se traços simpáticos e traços antipáticos, a fim de aumentar a participação afetiva do telespectador, tanto no seu apego pelos heróis, como na sua repulsa pelos maus (Morin, 1984).

\subsubsection{Política}

Na sociedade espetacular pós-moderna, a política manifesta-se invadida pelas ações íntimas e pessoais: a política se privatiza - a vida privada do governante, em muitos momentos, ocupa toda a cena pública. A abordagem das notícias no JN, muito mais que convencer ou explicar, tem como estratégia seduzir e arrebatar o telespectador.

Trata-se de uma espécie de política da vida privada, exibição da intimidade doméstica e psicológica na qual a política se banaliza nas pequenas coisas cotidianas, se enuncia nos discursos ordinários, se dissemina nos traços quase imperceptíveis da fisionomia. Nesse âmbito, a política se deteriora em uma verdadeira teatralidade mercantil.

Desta perspectiva, pode-se inferir que, no período analisado, ocorre uma verdadeira salada de discursos, envolvendo notícia, festa, eventos e fait-divers: 
Trab.Ling.Aplic., Campinas, 45(1) - Jan./Jun. 2006

Rep: O presidente Lula veio ao Rio para a comemoração dos 50 anos da Petrobrás.. (JN 03/ $10 / 03)$

Her: E o presidente Luís Inácio Lula da Silva esteve na abertura da October Fest.

Rep: Em Blumenau o presidente Lula usou o tradicional chapéu tirolês e Hoje em Porto Alegre, participou da inauguração da Quarta Bienal de Artes Visuais do Mercosul (...)

Her: No fim da tarde o presidente participou da exposição Feira Agropecuária Industrial e Comercial em Chapecó, no oeste de Santa Catarina. (JN 04/10/03)

Bon: Lula participou da abertura de um fórum internacional de microcréditos em Brasília. A rainha Sofia da Espanha também estava presente. (JN 06/10/03)

Bon: O presidente Lula recebeu hoje os reis da Noruega em Brasília. (...) Agora à noite o presidente e o casal real assistem a um espetáculo com artistas brasileiros e noruegueses. A renda vai para o programa fome zero. (JN 07/10/03)

Essa passagem do espaço público para a condição "panoptium mercantilizado" vem acompanhada de uma série de léxicos que sinalizam fortes apelos à subjetividade: desagradou, temem perder, queremos benefício, só um tratamento igual, defenda a sua condição, queremos exatamente, está preocupado, perda de arrecadação, alertam para o risco, sou a favor, tem que ter, assegure, reação da cúpula, provocou reações, pretende derrubar...

A lógica é a mesma ao recorrermos ao vocabulário utilizado: deseja, apoiar, consolidar, assegurar, querem aprovar, gostaram, não gostou, acertaram, defende, entre outros. Ou seja, discursos que teoricamente deveriam ser construídos sob a premissa da credibilidade, da objetividade e da seriedade, são estranhamente fragilizados, através do uso de léxicos e vocábulos pertencentes ao campo da modalização subjetiva explícita.

Os discursos direto e indireto são usados com bastante ocorrência, porém, o discurso indireto merece destaque: e a ministra disse ainda que...; Lula disse que...; Segundo a família...; O presidente reafirmou hoje...; hoje Lula reafirmou que...; O presidente Lula lembrou da promessa...; o presidente disse que imóveis... Através deste tipo de discurso, o repórter detém uma infinidade de maneiras para traduzir as falas dos políticos e das outras vozes legitimadas, pois não são as palavras exatas que são relatadas, mas, sim, o conteúdo do pensamento.

Há pouco uso de voz passiva e nominalizações, principalmente no que se refere à política brasileira, o que enfatiza e explicita a agência dos envolvidos na esfera política. Provavelmente isso acontece pelo caráter meramente descritivo das ações dos políticos por parte do $\mathrm{JN}$, que não se reporta às causas dos fatos, nem pretende omitir a responsabilidade de quem está falando.

Contudo, é preciso fazer algumas ressalvas com relação aos casos em que aparece a voz passiva: em relatos de morte e de assuntos relacionados a dinheiro - ofuscando, por sua vez, a agência dos envolvidos nos processos:

Fat: Só amanhã devem ser resgatados os corpos do presidente do PTB José Carlos Martinez (...)

Bon: A ministra de Minas e Energia Dilma Rossef anunciou hoje um programa de eletrificação rural para beneficiar 10 milhões de brasileiros. Serão atendidos 2 milhões e meio de domicílios e famílias com renda inferior a 3 salários mínimos por mês. Pra isso serão investidos 7 bilhões de 
CARVALHO \& GOMES - Desvendando as implicações político-ideológicas...

reais nos próximos 5 anos. E a ministra disse ainda que o governo decidiu vender, de forma pulverizada, ações da Eletrobrás, mas ressaltou que o Estado vai continuar com $51 \%$ das ações. (JN 06/10/03)

As críticas remetidas ao governo são, em grande parte, atenuadas pelo futuro do pretérito, com o intuito de resguardar as autoridades políticas do nosso país, além de não correr o risco de lançar uma crítica potencialmente ameaçadora à paz nacional. Podemos observar tais questões nos exemplos: seria, tributaria, deixariam, seriam construídas, poderiam, pagaria as despesas, teriam expressado, teria aproveitado, evidenciariam, etc.

\section{CONSIDERAÇÕES FINAIS}

A análise desenvolvida possibilita, enfim, evidenciar algumas considerações significativas acerca do Padrão Globo e da qualidade das informações veiculadas pelo JN. Levando em consideração o questionamento recorrente se "estamos bem informados?", pode-se concluir, através dos dados obtidos, que a resposta é "não", não estamos bem informados. O que ocorre é que estamos sendo formatados, condicionados à realidade fabricada pela tecnologia do poder articulada pela Rede Globo, poder disciplinador e controlador. Com efeito, o poder produz não só realidades, mas também campos de objetos e rituais da verdade (Foucault, 1977).

Nesse sentido, pode-se dizer que o telejornal JN conserva sua hegemonia global e sustenta sua credibilidade através da disciplina e do controle, ou melhor, do adestramento para o espetáculo, modelando gostos e comportamentos dos telespectadores. Conforme destaca Foucault (1977), a disciplina é um tipo de poder discreto, pois funciona permanentemente e, na maioria das vezes, em silêncio:

O poder disciplinar é com efeito um poder que, em vez de se apropriar ou de retirar, tem como função maior adestrar. Adestrar as multidões confusas, móveis, inúteis de corpos e forças para uma multiplicidade de elementos individuais (...). A disciplina fabrica indivíduos, ela é a técnica específica de um poder que toma os indivíduos ao mesmo tempo como objetos e como instrumentos de seu exercício (Foucault, 1977).

Como pode ser observado, a estratégia do adestramento se dá sob os mais variados nuances, tanto no âmbito verbal no que se refere ao atravessamento de discursos ufanistas, nacionalistas, hegemônicos de manutenção da ordem social e freqüência de editorias. Tudo é preparado para ser absorvido sutilmente. Trata-se da dialética atemorização $\mathrm{x}$ tranquilização, que compõe o fato e o cenário noticioso (Filho, 1989). Descargas de acontecimentos anormais, insólitos e curiosos ativam descargas de adrenalina, causando a erupção de emoções que são ativadas e desativadas pela própria dinâmica do JN.

Podemos ampliar ainda tal discussão, argumentando que além de ser um aparato disciplinador, o JN se coloca ainda como um instrumento de regulação e controle, que procura sustentar e conservar as hegemonias. 
É nesse ínterim que se estabelece a função promocional e manipuladora na linguagem e pelo discurso: eventos que se tornam notícias provém de um grupo limitado que tem acesso privilegiado à mídia e são tratados como fontes confiáveis. Nesse sentido, vozes de pessoas legitimadas na versão cotidiana fazem as identidades, as relações e distâncias entrarem em colapso. Tais fatos são conseqüência dos efeitos resultantes da chamada modernidade tardia, cujas tendências discursivas - democratização, comodificação e tecnologização - são amplamente discutidas pelo teórico Fairclough (2001).

Partindo-se da premissa de que o noticiário precisa conquistar a credibilidade do telespectador, a (pseudo) democratização do discurso atua no sentido de apagar assimetrias discursivas e lingüísticas, tornando a notícia acessível a qualquer cidadão comum., por meio principalmente do recurso à narrativização. Aparentemente, há uma tentativa de aproximação e cumplicidade na escolha das editorias de maior recorrência, uma espécie de "controle social de corações e mentes", mas isso não significa que o telejornal esteja informando devidamente.

Contudo, o enfoque deve ser direcionado, principalmente, à marquetização e a tecnologização: a primeira é fruto da estruturação das instituições sociais, inclusive os meios de comunicação, em termos de produção, distribuição e consumo de mercadorias; 0 segundo se dá pela colonização da vida pelo mundo dos sistemas, através do uso da técnica para fins de convencer e disciplinar.

Associadas, essas tendências sintetizam o panorama atual dos meios de comunicação, em especial o Jornal Nacional, em que a notícia tem sido colonizada pela lógica publicitária. Sob este viés, Marshall (2003) discute a atuação do mercado como mídia, que segmenta a sociedade civil, influi sobre o fluxo e a hierarquia do noticiário e aconselha a espetacularização televisiva de certos temas, confundindo os espíritos em nome de uma estratégia de vendas.

Desta perspectiva, Fairclough (2001) afirma que a mídia de notícias está no negócio competitivo de recrutar telespectadores, ouvintes e leitores em um contexto de mercado. $\mathrm{O}$ jornalismo contemporâneo é, hoje, tachado de cor-de-rosa justamente por apresentar os padrões éticos e estéticos necessários para agradar o capital.

\section{REFERÊNCIAS BIBLIOGRÁFICAS}

CARVALHO, F.; GOMES, M. C. A. (2204). A mídia telejornalística Jornal Nacional: vender para informar ou informar para vender. In: GOMES, Maria Carmen Aires e CAMPOS, Maria Cristina Pimentel (org.) Interações dialógicas: linguagem e literatura na sociedade contemporânea. Viçosa: Editora UFV. P.6582.

FAIRCLOUGH, N. (2001). Discurso e mudança social. Brasília: Editora UnB.

FILHO, C. M. (1989). O capital da notícia: jornalismo como produção social da segunda natureza. São Paulo: Ática.

FOUCAULT, M. (1977). Vigiar e Punir: nascimento da prisão. Petrópolis: Vozes. 
CARVALHO \& GOMES - Desvendando as implicações político-ideológicas...

GOMES, M. R. (2003). Poder no Jornalismo. Discorrer, Disciplinar, Controlar. São Paulo: Hacker Editores. Edusp.

GUIMARÃeS, E. (2001). Produção e Circulação do Conhecimento: Estado, Mídia e Sociedade. Campinas: Pontes.

GREGOLIN, M. do R. (org). (2003). Discurso e Mídia: a cultura do espetáculo. São Carlos: Claraluz.

HALLIDAY, M.A.K. (1994). An introduction to functional grammar. London: Edward Arnold.

KURTZ, H. (1993). Media Circus: the trouble with America's newspaper. Estados Unidos: Times Books.

MAINGUENAU, D. (2001). Análise de textos de comunicação. São Paulo: Cortez.

MARSHALL, L. (2003). O jornalismo na era da publicidade. São Paulo: Summus.

MEDINA, C. (1988). Notícia, um produto à venda: jornalismo na sociedade urbana e industrial. São Paulo: Summus. (2002). Entrevista: o diálogo possível. São Paulo: Ática.

MORIN, E. (1984). Cultura de massas no século XX. Rio de Janeiro: Forense. 